\title{
The Diffusion Process of the First Filial Silkworm in Japan (1915-1921)*
}

\author{
Tokihisa Dor
}

\section{Introduction}

Through the last two decades (since 1955), socalled "Quantitative Geography" or "Statistical Geography" has rapidly progressed in the whole world. Agricultural geography is no more considered a separate subject of agricultural economics at least in some topics. In particular the diffusion of technical innovation, the main topic of this paper, affects both geography and economics ${ }^{1}$.

The diffusion of $F_{1}$ hybrid ${ }^{2}$ in Japan is discussed in this paper as a problem of agricultural geography and economics. As is well-known, the diffusion of $F_{1}$ hybrid coupled with that of summer-autumn cocoon production rapidly increased Japanese raw silk production and its export to the United States between 1914 (the year of first introduction of $F_{1}$ hybrid into Japan) and 1930.

Before the wide diffusion of $F_{1}$ hybrid, Japan's cocoon production had the weak point of silkworm's less resistance against disease. From 1910 onwards some private silkworm egg producers had realized the value of hybrid ${ }^{3)}$ as means of overcoming the weak point. Their eggs were "fixed" and not so good as $F_{1}$ hybrid. The National Station for the Reproductive Silkworm Egg established in 1911 began to study $F_{1}$ hybrid since 1913. Prefectural Stations were also established all over the country. These Stations began to supply parent eggs of $F_{1}$ hybrid to private silkworm egg producers since 1914 and they spread rapidly throughout the country until 1921. These facts show the importance of the particular decade (1910-1920) for this study.

\section{Problems}

The auther reported the regional differences in cocoon production structure between the east and west parts of Japan by means of production func- tion analysis using the cross sectional data of 1932 $-34^{4)}$, in which the cocoon production cost was relatively higher in the west part of Japan but the reasons were not discussed. To find what elements led to the differences, a time series analysis is effective.

The objective of this paper is to learn about the diffusion process of $F_{1}$ hybrid silkworm compared with that of native silkworm variety. To make the problems clearer, basic facts concerning cocoon production will be presented as follows.

In Japan the price of cocoons showed a downward trend but cocoon production showed a clear upward trend from 1890 to 1930, as shown in Fig. ures 1 and 2. From this it would be reasonable to suppose the existence of substained technical progress in cocoon production. On this point, Fujino (1965) made a quantitative analysis. Recently, Shintani (1975 b) measured the supply response elasticities of cocoon. He calculated the relationship between the increase of land productivity and of mulberry field area to total cocoon product. In his second period (1900-1920)5) the contribution rate of land productivity increase to total cocoon product increase was 46 percent and that of mulberry field was 54 percent. However, Figure 2 shows that the rate of growth of land productivity is almost zero from from 1900 to 1910 . On the contrary, the total product of cocoons and land productivity indicate nearly the same rates of growth from 1910 to 1920. This same figure instructs that the two rates of growth are higher in the later half of the 1910's than in the former half, i.e. the importance of $F_{1}$ hybrid diffusion in the later half of the 1910 's. In this period the contribution of land productivity to total cocoon production due to $F_{1}$ hybrid should be much greater than Shintani's 46 percent.

In the following sections, the author will review 


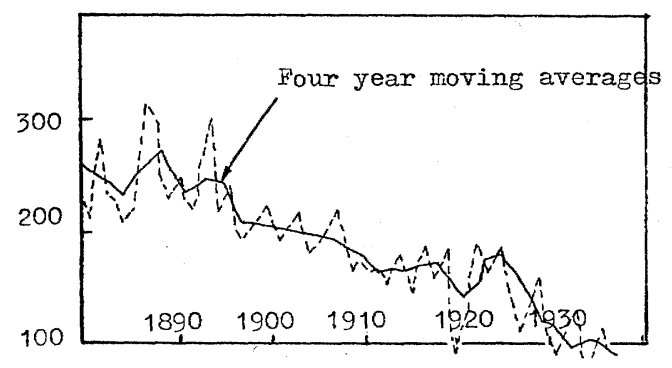

Figure 1 The trend of cocoon price rate to wholesale price

Source: Fujino (1965)

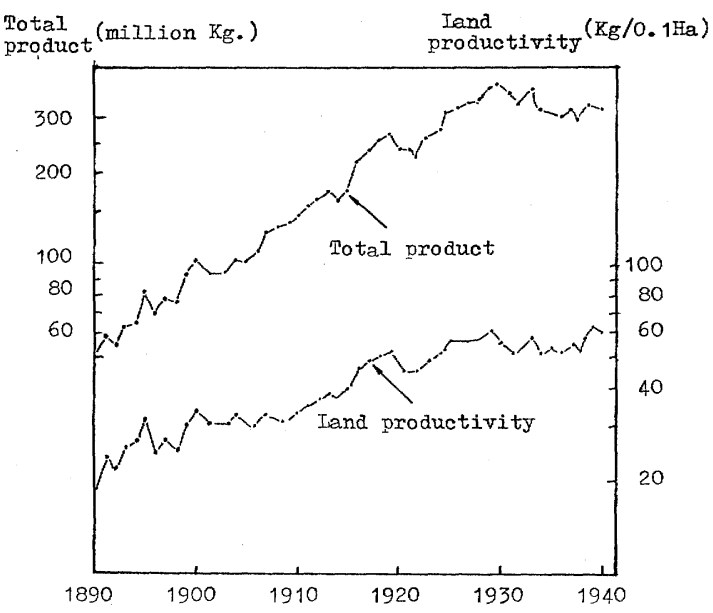

Figure 2 Trend of total product and land productivity

Source: MAF (1961) Yosan Ruinen Tokeihyo Time-series Statistics of Sericulture

some previous studies on the diffusion process of agricultural innovations in Japan, the studies of $F_{1}$ hybrid silkworm and several quantitative analyses on cocoon and raw silk production. Next he will outline the method which reduce the differences of spatiotemporal data to the values of three parameters, and then examine the computed results, and try multiregression analysis to find out the elements which determine the diffusion of $F_{1}$ hybrid. Finally, some conclusions will be drawn and limitations of this study will be mentioned.

\section{Previous studies; a review}

1) Some recent studies on the diffusion process of innovations in Japanese agriculture

Several studies have been reported in Japan concerning which elements determine the diffusion process of agricultural innovation such as new rice varieties and protected ricenursery. The serial studies on the diffusion of 'post-war developed rice varieties' by Sakiura (1974 a, b, 1976) are typical ones. Using logarithmic reciprocal transformatfion method, somewhat modified from the method by Griliches (1957), he estimated the parameter; 'rate of retardation' by prefectures. Then, by means of regression analysis, setting 'rate of ietardation' as dependent variable, he drew some important conclusions. He found that rice in Japan and hybrid corn in the United States do not have similar diffusion curve. The diffusion curve of rice in Kyushu did not occur with hybrid corn. $\mathrm{He}$ named this diffusion curve of rice in Kyushu the ' $\mathrm{K}$ type curve ${ }^{96}$ which has the following characters; (1) the origin of diffusion was later than any other regions, (2) there was a lower rate of acceptance in the early period of diffusion and (3) a spurt in the rate of acceptance in the later period which reaches near the 'ceiling'.

For the diffusion of protected rice-nursery, Otsuka (1975) also adopted Griliches's logistic curve method and applied regression analysis. He point ed out a rather complicated diffusion process in his empirical study. In the course of diffusion of protected rice-nursery, the material for protection shifted from oil paper to vinyl sheet and this new material accelerated the rate of acceptance. $\mathrm{He}$ stresses the importance of the shift as an improvement in technology. It is this improved technique, he concludes, that characterize the diffusion process of protected nursery. He also says that this process of diffusion is not simply that of a given technology but a successive diffusion of an improved one following the diffusion of a basic technology.

That is to say there was a 'dual and serial process of diffusion'.

In conclusion, from the view point of method, we can recognize a common character in the studies mentioned above. They tried to fit the data to a kind of diffusion functions to estimate some parameters, and analyzed these parameters by means of regression.

2) Some critical notes on the studies of the diffusion process of first filial silkworm 
Table 1 Comparison of Silkworm Characters

\begin{tabular}{l|cccccc}
\hline \hline & $\begin{array}{c}\text { Average } \\
\text { duration } \\
\text { of feeding } \\
\text { period } \\
\text { (day) }\end{array}$ & $\begin{array}{c}\text { Rate of } \\
\text { decrease in } \\
\text { silkworm } \\
\text { number } \\
(\%)\end{array}$ & $\begin{array}{c}\text { Rate of } \\
\text { double } \\
\text { cocoon } \\
(\%)\end{array}$ & Length & Value & Size \\
\hline Japanese race & 31.22 & 21.2 & 8.4 & 547.9 & 0.2149 & 3.00 \\
Chinese race & 29.05 & 19.6 & 4.9 & 604.7 & 0.1917 & 2.54 \\
F 1 hybrid & 29.08 & 13.4 & 12.6 & 639.7 & 0.2288 & 3.01 \\
\hline
\end{tabular}

Source: Matsuo (1962) p. 636

Table 1 indicates the hybrid vigor rates at the beginning period of $F_{1}$ hybrid diffusion. Generally speaking, $F_{1}$ hybrid is shorter in duration of feeding period, lower in loss in silkworm number, larger in length, value and size. Its economical advantages are the stability of production and the increase of land productivity.

The auther's survey on the previous studies of $F_{1}$ hybrid diffusion leads to the following three points. First, there are contradicting reports in evaluating the policy of $F_{1}$ hybrid distribution by government stations to private silkworm producers in the later half of 1910's. Hayakawa (1923) considers that government policy of distributing parent eggs of $F_{1}$ hybrid had a great role in accelerating the diffusion of $F_{1}$ hybrid. On the contrary, Ishii (1972) admits the role of large-scale raw silk production firms which also made $F_{1}$ hybrid silkworm eggs. $\mathrm{He}$ insists that the role of government stations was relatively small. He says, the role of government stations went up like a rocket and came down like a stick'. To settle this controversy, detail quantitative investigation is needed.

Second, there is an opinion that $F_{1}$ hybrid was improved for the profit of large scale machine filature. According to Kondo (1932), $F_{1}$ hybrid could not diffuse so rapidly among sericultural farmers, because machine filatures needed good homogeneous cocoon over the conservativeness of farmers.

This remarks is worthy of reconsideration, if it mentions about later half of 1910's. As a matter of fact, rate of acceptance of this period was very high. For the time being, it will be reasonable to suppose his remarks are concerning about the period after 1920 , because after the year $F_{1}$ hybrid was extensively improved.
Third, the traditional division in $\mathrm{MAC}^{7}$ statistics for raw silk producer into hand reeling filature and machine filature is inappropriate to study the diffusion of $F_{1}$ hybrid. Ishii (1972) points out the importance of the idea of 'first type' and 'second type' machine filature. The former is defined as high quality raw silk producer. Distribution of this type was limited mainly to the west part of the country. In the 1910's the demanded quality of raw silk shifted rapidly from normal one for woof to 'extra fine' or 'extra' grade which was used for warp. Some of the 'second type' machine filature tried to transform themselves into the 'first type'. To make the transformation possible, the filatures had to have a special business relationship with sericultural farmers called 'the system of especially contracted trade of cocoons' (tokuyaku-torihiki: i.e. the contract that the filatures supply $F_{1}$ hybrid eggs to sericultural farmers and buy all produced cocoons from farmers). This system guaranteed the filatures to keep enough homogeneous high quality cocoons.

3) On the quantitative analyses of cocoon and raw silk production

Fujino (1965) examined the relationship between cocoon price and product using a kind of lag model. The investigation of raw silk production in the Meiji era from the view point of technological progress (Otsuka 1972) is also noteworthy. Concerning with diffusion of innovation and changes in consumer demand structure, Hayami and Sato (1964) studied post-war cocoon production.

After his quantitative analysis of rice production (1970) and 'quantitative economic historical studies' (1972 a, b), Shintani recognized the importance of the cocoon production from the view point of agri- 
cultural development in Japan (Shintani 1975 a, b, c). His study on the supply response of cocoon production (1975 b) made clear the successive shift of the cocoon supply curve. Possitively taking into account the technological progress, he built a skilful model of demand and supply relation of cocoons. Utilizing the model, he calculated the elasticities of cocoon supply and rates of shift of supply curve including other parameters. Table 2 is reproduced from his estimation ${ }^{8)}$.

The highest elasticity and rate of shift are seen in his second period in which the time of the auther's research is included. These high values, he says, are owing to the diffusion of summer and autumn rearing, decreased rate of fault crop and remunerative terms of family labour. As ground for his third period shift, he cites the diffusion of $F_{1}$ hybrid. In oposition to Shintani's explanation, the auther considers that $F_{1}$ hybrid diffusion shifted the supply curve in his second period.

The above review leads us to believe the importance of $F_{1}$ hybrid in the later half of the 1910's. So far as the author's knowledge goes, any quantitative approach to the diffusion process of $F_{1}$ hy. brid has not been tried.

Table 2 The supply elasticities and rates of supply curve shift

\begin{tabular}{c|cc}
\hline \hline Periods & Elasticities & $\begin{array}{c}\text { Rates of shift } \\
\text { (percent/year) }\end{array}$ \\
\hline $1 ; 1880-1900$ & 0.78 & 4.79 \\
$2 ; 1900-1920$ & 2.78 & 7.71 \\
$3 ; 1920-1930$ & 0.87 & 5.28 \\
$4 ; 1930-1935$ & 0.15 & -1.53 \\
\hline
\end{tabular}

Source : Shintani, M. (1975 b)

\section{Theoretical considerations}

A graphical time path of the rates of $F_{1}$ hybrid egg to total egg by prefectures generally looks as $\mathrm{S}$-shape. There are several kinds of S-shaped trend functions and the choice of a particular function is somewhat arbitrary. The author tried tentatively to fit three types of trend functions (i.e. the logistic, the logarithmic reciprocal and the Gomperts) to the data. The logistic curve seemed to be best.

The logistic curve ${ }^{9)}$ is defined by

$$
P=K /\left[1+e^{-(a+b t)}\right]
$$

where $P$ is percentage of $\mathrm{F}_{1}$ hybrid egg,

$K$ : ceiling or equilibrium value,

$t$ : time variable, and a constant ${ }^{10)}$.

The logistic is easily transformed into the following equation linear in ' $\mathrm{a}$ ' and ' $\mathrm{b}$ '11.

$$
\ln [P /(K-P)]=a+b t
$$

The formula (2) allows us to estimate the parameters directly by OLS. The value of $K$ was determined by reducing frorn 100 percent to actual rate at 1921 by one percent, then the value of $K$ was found which maximizes the coefficient of determination.

\section{The first filial silkworm logistic trend by pre- fectures}

The procedure outlined in the previous section was applied to estimate parameters of logistic functions for 46 prefectures with the data by Ministry of Agriculture and Commerce $(\mathrm{MAC})^{12}$. The data for 1920 were not available, and the gap was interpolated. We have no method of checking the reliability of the data. The available data before 1917 indicates to the author that certain values are missing. In such cases, interpolation was again adopted. In this paper the calculation is limited only to egg for spring rearing. The available data for summer and autumn rearing cover only two years and make it impossible to fit the logistic curve to the data. Comparing those data with that of spring rearing, the rates of $F_{1}$ diffusion are lower in the former than in the latter.

The result of the calculations are presented in Table 3. Time is measured in year from 1915, and P10, P50 and P85 mean the year when the logistic function passed through the 10,50 and 85 percent value respectively. P10 indicates sometimes below the 'origin'. The columns $a, b$ and $K$ correspond with those in formula(2).

The followings are noteworthy about the figures in Table 3. In general, $r^{2}$ keeps high value except some prefectures in the west. Lower values of $r^{2}$ 
Table $3 \quad F_{1}$ hybrid silkworm egg logistic functions

\begin{tabular}{|c|c|c|c|c|c|c|c|c|}
\hline \multicolumn{2}{|r|}{ prefecture } & \multirow{2}{*}{$\frac{\mathrm{P} 10}{3: 68}$} & \multirow{2}{*}{$\frac{\mathrm{P} 50}{4.78}$} & \multirow{2}{*}{$\begin{array}{l}\text { P85 } \\
5.85\end{array}$} & \multirow{2}{*}{$\begin{array}{c}a \\
-9.74\end{array}$} & \multirow{2}{*}{$\begin{array}{c}b \\
2.07\end{array}$} & \multirow{2}{*}{$\begin{array}{c}K \\
0.93\end{array}$} & \multirow{2}{*}{$\frac{r^{2}}{0.96}$} \\
\hline 1 & Hokkaido & & & & & & & \\
\hline 2 & Aomori & -0.88 & 2.04 & 5.02 & -1.42 & 0.78 & 0.92 & 0.87 \\
\hline 3 & Iwate & 3.29 & 4.63 & 6.25 & -7.76 & 1.73 & 0.89 & 0.94 \\
\hline 4 & Miyagi & 0.79 & 2.84 & 4.46 & -3.04 & 1.07 & 1.00 & 0.95 \\
\hline 5 & Akita & 2.39 & 3.55 & 4.47 & -6.71 & 1.89 & 1.00 & 0.90 \\
\hline 6 & Yamagata & 3.12 & 4.24 & 5.26 & -8.38 & 2.00 & 0.95 & 0.91 \\
\hline 7 & Fukushima & 0.53 & 2.60 & 4.41 & -2.72 & 1.08 & 0.96 & 0.97 \\
\hline 8 & Ibaragi & 2.81 & 4.22 & 5.39 & -6.59 & 1.57 & 0.98 & 0.91 \\
\hline 9 & Tochigi & -1.89 & 2.50 & 5.97 & -1.25 & 0.50 & 1.00 & 0.74 \\
\hline 10 & Gunma & 1.96 & 3.79 & 5.75 & -4.54 & 1.25 & 0.91 & 0.96 \\
\hline 11 & Saitama & 2.48 & 4.16 & 5.74 & -5.45 & 1.34 & 0.94 & 0.93 \\
\hline 12 & Chiba & 3.38 & 4.99 & 6.37 & -6.83 & 1.38 & 0.97 & 0.97 \\
\hline 13 & Tokyo & 0.39 & 2.63 & 4.40 & -2.58 & 0.98 & 1.00 & 0.83 \\
\hline 14 & Kanagawa & -2.00 & 1.73 & 4.67 & -1.02 & 0.59 & 1.00 & 0.70 \\
\hline 15 & Niigata & 3.16 & 4.33 & 5.28 & -8.12 & 1.88 & 0.99 & 0.97 \\
\hline 16 & Toyama & 3.26 & 4.39 & 5.41 & -8.67 & 2.00 & 0.95 & 0.89 \\
\hline 17 & Ishikawa & 2.69 & 4.10 & 5.25 & -6.38 & 1.56 & 0.99 & 0.93 \\
\hline 18 & Fukui & 3.02 & 4.24 & 5.73 & -7.77 & 1.89 & 0.89 & 0.95 \\
\hline 19 & Yamanashi & 4.16 & 6.62 & 9.85 & -6.01 & 0.95 & 0.88 & 0.98 \\
\hline 20 & Nagano & 2.95 & 4.49 & 6.23 & -6.51 & 1.50 & 0.90 & 0.96 \\
\hline 21 & Gifu & 1.89 & 3.64 & 5.10 & -4.55 & 1.26 & 0.98 & 0.93 \\
\hline 22 & Shizuoka & 2.37 & 4.53 & 6.84 & -4.60 & 1.06 & 0.91 & 0.85 \\
\hline 23 & Aichi & -4.72 & 1.94 & 7.20 & -0.64 & 0.33 & 1.00 & 0.82 \\
\hline 24 & Mie & 1.68 & 3.29 & 4.57 & -4.48 & 1.36 & 1.00 & 0.93 \\
\hline 25 & Shiga & 2.79 & 3.78 & 4.56 & -8.39 & 2.22 & 1.00 & 0.95 \\
\hline 26 & Kyoto & 0.07 & 1.47 & 2.59 & -2.30 & 1.56 & 1.00 & 0.91 \\
\hline 27 & Osaka & -0.76 & 1.89 & 3.98 & -1.57 & 0.83 & 1.00 & 0.92 \\
\hline 28 & Hyogo & 1.33 & 2.44 & 3.32 & -4.83 & 1.98 & 1.00 & 0.90 \\
\hline 29 & Nara & -0.02 & 1.94 & 3.49 & -2.17 & 1.12 & 1.00 & 0.91 \\
\hline 30 & Wakayama & 0.79 & 2.17 & 3.26 & -3.45 & 1.59 & 1.00 & 0.98 \\
\hline 31 & Tottori & 1.80 & 2.90 & 3.77 & -5.80 & 2.00 & 1.00 & 0.94 \\
\hline 32 & Shimane & 0.27 & 2.58 & 4.40 & -2.45 & 0.95 & 1.00 & 0.84 \\
\hline 33 & Okayama & 1.47 & 3.03 & 4.26 & -4.27 & 1.41 & 1.00 & 0.85 \\
\hline 34 & Hiroshima & 1.56 & 3.10 & 4.35 & -4.41 & 1.43 & 0.99 & 0.88 \\
\hline 35 & Yamaguchi & -0.98 & 2.11 & 4.56 & -1.50 & 0.71 & 1.00 & 0.40 \\
\hline 36 & Tokushima & 0.28 & 1.95 & 3.26 & -2.57 & 1.32 & 1.00 & 0.90 \\
\hline 37 & Kagawa & 2.02 & 3.31 & 4.33 & -5.63 & 1.70 & 1.00 & 0.85 \\
\hline 38 & Ehime & 2.58 & 4.34 & 5.72 & -5.42 & 1.25 & 1.00 & 0.69 \\
\hline 39 & Kochi & 2.64 & 4.06 & 5.18 & -6.29 & 1.55 & 1.00 & 0.73 \\
\hline 40 & Fukuoka & -2.38 & 0.20 & 2.24 & -0.17 & 0.85 & 1.00 & 0.54 \\
\hline 41 & Saga & 0.23 & 2.62 & 4.51 & -2.41 & 0.92 & 1.00 & 0.63 \\
\hline 42 & Nagasaki & 0.68 & 2.99 & 4.82 & -2.84 & 0.95 & 1.00 & 0.96 \\
\hline 43 & Kumamoto & 0.48 & 2.99 & 5.02 & -2.61 & 0.88 & 0.99 & 0.64 \\
\hline 44 & Oita & 0.87 & 3.00 & 4.68 & -3.09 & 1.03 & 1.00 & 0.70 \\
\hline 45 & Miyazaki & -0.02 & 2.29 & 4.12 & -2.18 & 0.95 & 1.00 & 0.47 \\
\hline 46 & Kagoshima & 2.68 & 3.90 & 4.86 & $-7: 20$ & 1.80 & 1.00 & 0.93 \\
\hline
\end{tabular}

$\ln [P /(K-P)]=a+b t ; t_{1915}=1$;

$\mathrm{P} 10=$ 'origin' (year of 10 per cent) e.g.,

$-2=1912, \quad 0=1914, \quad+2=1916, \quad+4=1918$. 
than 0.80 are omitted in the regression analysis because these are not correctly indicated by the logistic curve. P10 seems to be earlier in the west. The rates of acceptance $(b)$ look rather uniform.

On the contrary, ceilings $(K)$ are quite different regionally and have apparently lower values in the east and almost an unit value in the west which means complete diffusion of $F_{1}$ hybrid in the equilibrium stage.

\section{T-test on three parameters : origin, rate of acceptance and ceiling}

Taking the conclusions of the previous study (Doi 1974) into consideration, the author intended to examine any difference in the mean values of three parameters between the east and west parts of Japan and applied the student's t-test (Table 4).

The east 22 prefectures (number 1-22) and the west 24 (number 23-46) are grouped.

Table 4 indicates the following facts: (1) the origin differs at one percent level ; the mean year of origin is around 1917 in the east group and nearly 1915 in the west ; (2) the difference is not noticeable for the rate of acceptance; and (3) the equilibrium levels are quite different : about 0.95 , i.e. 95 percent in the east, on the other hand, close to one, i.e. 100 percent in the west.

The values of three parametes are not independent to each other. Therefore, a kind of compre- hensive method should be applied for the analysis. ${ }^{13)}$ But, as a preliminary stage, it is sufficient to treat them separately. From the view point of $F_{1}$ hybrid diffusion, the fact (1) is important. Hence, the regression analysis is applied to 'origin' in the next section.

\section{Regression analysis on 'origin'}

Some examples of logistic trend curves are shown in Figure 3. The curve of Kyoto shows lower P10 value and relatively rapid diffusion of $F_{1}$ hybrid. Kyoto, Hyogo and Mie in the west group have similar pattern of curve. The other three curves indicate the east type diffusion process. The exceptionally low rate of acceptance (also the lowest value of equilibrium and the highest value of origin) is shown by the curve of Yamanashi prefecture. Such patterns of curves are consistent with the results of $t$-test mentioned above.

The author attempts a tentative regression analysis for the 'origin' as a first step, because it seems the most important parameter which characterizes $F_{1}$ hybrid diffusion. According to the previous studies on the diffusion of $F_{1}$ hybrid, the following four explanatory variables are taken into account : the ratios of cocoons traded by 'the system of especially contracted trade of cocoons ${ }^{14)}$ to total traded cocoons (variable $\mathrm{X}_{1}$ ), the ratio of parent eggs of $F_{1}$ hybrid distributed by government sta-

Table 4 T-test for the parameters: $\mathrm{P} 10, b$ and $K$

\begin{tabular}{|c|c|c|c|c|c|}
\hline Variable & Group & Mean & $\begin{array}{l}\text { Standard } \\
\text { deviation }\end{array}$ & $\begin{array}{l}\text { Standard } \\
\text { error }\end{array}$ & F-value \\
\hline P10 & $\begin{array}{l}\text { The east } \\
\text { The west }\end{array}$ & $\begin{array}{l}2.18 \\
0.93\end{array}$ & $\begin{array}{l}1.828 \\
0.970\end{array}$ & $\begin{array}{l}0.390 \\
0.269\end{array}$ & $3.55^{*}$ \\
\hline$b$ & $\begin{array}{l}\text { The east } \\
\text { The west }\end{array}$ & $\begin{array}{l}1.47 \\
1.43\end{array}$ & $\begin{array}{l}0.464 \\
0.388\end{array}$ & $\begin{array}{l}0.099 \\
0.108\end{array}$ & 1.43 \\
\hline$K$ & $\begin{array}{l}\text { The east } \\
\text { The west }\end{array}$ & $\begin{array}{l}0.95 \\
0.99\end{array}$ & $\begin{array}{l}0.043 \\
0.003\end{array}$ & $\begin{array}{l}0.009 \\
0.001\end{array}$ & $236.40^{* *}$ \\
\hline Variable & $\mathrm{t}$-value & d.f. & $\begin{array}{l}2 \text {-tail } \\
\text { prob. }\end{array}$ & & \\
\hline P10 & 2.64 & 32.76 & 0.013 & (Separate & e estimate) \\
\hline$b$ & 0.26 & 33 & 0.808 & (Pooled va & estimate) \\
\hline$K$ & 4.80 & 21.30 & 0.000 & (Separate & estimate) \\
\hline
\end{tabular}




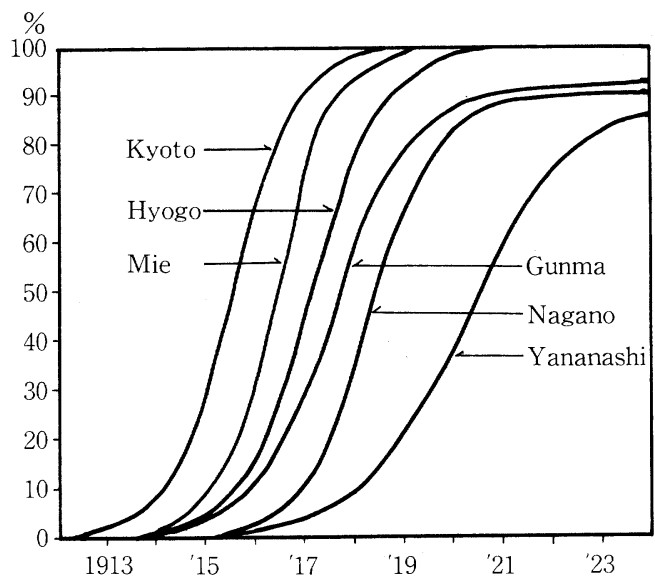

Figure 3 The logistic trend curves Graphed by the X-Y plotter using parameters in Table 3.

tions to total eggs (variable $\mathrm{X}_{2}$ ), the price of cocoons (yen per $k o k u$ ) as a measure of 'the quality difference' among prefectures (variable $\mathrm{X}_{3}$ ) and land productivity of mulbery lieves ( $k a n$ per $\tan$ ) as a measure of 'limitative factor' (variable $\left.\mathrm{X}_{4}\right)^{15}$.

The regression of origin on these four variables are presented in Table 5. The coefficients of all variables are significantly different from zero. Except for the coefficient of variable $\mathrm{X}_{2}$, these coefficients have expected signs. The coefficient of determination is fairly low. It would seem that this analysis could be improved by the addition of other variables; also $\mathrm{X}_{2}$ needs to be reexamined. The variable $\mathrm{X}_{2}$ was calculated from the data covering 1915-1919. It might be better to calculate $\mathrm{X}_{2}$ including earlier period of fixed hybrid acceptance.

It may be said that 'the especially contracted cocoon trade system' was closely related with acceleration of the diffusion of $F_{1}$ hybrid. The cocoon price in the east and the west was 69.7 yen and 76.3 yen per koku respectively in 1917 (significantly differs at 5 percent level). It seems to suggests the existence of close relationship between high quality cocoon production and the so-called 'first type filatures' in the west. The coefficient of $\mathrm{X}_{4}$ may indicates that the high productivity of the mulberry leaves was also an accelerated element of 'origin'. The evaluation of the policy of distribu-
Table 5 Regression of 'origin' on $\mathrm{X}_{1}, \mathrm{X}_{2}, \mathrm{X}_{3}$ and $\mathrm{X}_{4}$

\begin{tabular}{cccc|c}
\hline \hline \multicolumn{3}{c|}{ Coefficients of } & \multirow{2}{*}{$\overline{\mathrm{R}}^{2}$} \\
\cline { 1 - 3 } $\mathrm{X}_{1}$ & $\mathrm{X}_{2}$ & $\mathrm{X}_{3}$ & $\mathrm{X}_{4}$ & \\
\cline { 1 - 3 }-0.021 & 0.031 & -0.079 & -0.003 & \multirow{2}{*}{0.27} \\
$(2.87)$ & $(3.35)$ & $(2.57)$ & $(1.68)$ & \\
\hline
\end{tabular}

Regression

$\mathrm{P} 10=\mathrm{b}_{0}+\mathrm{b}_{1} \mathrm{X}_{1}+\mathrm{b}_{2} \mathrm{X}_{2}+\mathrm{b}_{3} \mathrm{X}_{3}+\mathrm{b}_{4} \mathrm{X}_{4}+\mathrm{u}$

Figures in parentheses are calculated $t$-values.

$\overline{\mathrm{R}}^{2}$ : Adjusted coefficient of determinant

ting $F_{1}$ hybrid eggs remains for further study.

\section{Limitation, summary and conclusions}

This paper does not claim to have thoroughly investigated all the factors that should be studied. The author hopes to take his research further at a later date. However certain progress has been made through this study. It has been made clear which elements determine the diffiusion of $F_{1}$ hybrid. In spite of somewhat inaccurate data, the logistic trend functions have been estimated by prefectures. Then, the regional differences of parameters, P10 and $\mathrm{K}$, between the east and the west have been revealed by t-tests. Finally, a tentative regression analysis was adopted to investigate which elements determine the level of P10.

However, the reserch described in this paper was not able to adequetely evaluate the distribution of eggs for $F_{1}$ hybrid by government stations.

Although the study is preliminary, some conclusions may be drawn from the above analysis. First of all, the very rapid spread of $F_{1}$ hybrid is noteworthy (within about five years more than 80 percent of local eggs were replaced by $F_{1}$ hybrid eggs). This might be the most rapid diffusion of any agricultural innovation. Secondly, the differences have been shown between the east and the west of Japan in parameters: origin and equilibrium level. Finally some of the elements which determine the level of origin were discovered.

The auther wishes to express his thanks to Professors Seiji Sakiura, Masahiko Takashima and Toshio Kuroyanagi, and graduate students of Agricultural Economics, Hokkaido Univ., for their comments on earlier draft. He is also grateful for the comments which were 
given at the meeting of Tohoku Geographical Association from Professors Ken-ichi Tanabe and Kenji K. Oshiro. Professor Yoshihiro Nakano, Hokkaido College of Education, wrote the computer program for the $\mathrm{X}-\mathrm{Y}$ plotter and gave valuable suggestions during the study. Appreciation is also expressed to Professor Kasuke Nishimura and anonymous referees for helpful comments. The caluculations in this paper were computed at HUCC applying 'SPSS (FACOM 6th version)' program package.

However, the auther assumes full responsibility for any remaining errors and omissions.

(1977.1.17 受理)

\section{Notes}

* Revised from the paper presented at the Ann. Meet. Tohoku Geogr. Ass., Apr., 1976.

1) Yeates (1968) treats the model of diffusion pattern of agricultural innovation curve and markov chains.

2) For the simplicity, the word ' $F_{1}$ hybrid (silkworm egg)' will be used instead of 'first filial silkworm egg' in this paper.

3) 'Kiishimaru' and 'Sanryumata' produced by the Sanryusha Co. are typical instances.

4) Doi (1974)

5) He divided from 1880 to 1935 , for the comparative static study, into following four periods.

$1: 1880-1900,2: 1900-1920,3: 1920-1930,4$ : $1930-1935$

6) The ' $K$ type curve' was precisely analysed in Sakiura (1976).

7) Ministry of Agriculture and Commerce (MAC) : later Ministry of Agriculture and Forestry (MAF).

8) Quoted from Tables 3 and 5 in Shintani (1975 b)

9) In tentative calculation, the logistic curve

$$
P=K /\left[1+e^{-(a+b t)}\right]+C, \quad C>0
$$

was applied to the prefectures which start from above 15 percent at 1915 . The fitness was not so good as that which applied formula (1).

10) For the features of this curve, see Griliches (1957) section 2.

11) See Yeates (1968) Appendix 1.
12) Source: 1915-1919; 'The Dainippon Sanshikai-ho' Nos. 291, 311, 325, 335. 1921; 'The Sangyo Shinpo' No. 345.

13) Regarding this point, see a canonical analysis (Doi 1977).

14) See the later part of section 3-3.

15) The sources of these variables are as follows. $\mathrm{X}_{1}$; Ishii (1972) p. 428, $\mathrm{X}_{2} ; \operatorname{MAC}(1920), \mathrm{X}_{3}$; MAC (1918), X ; MAF (1927)

MAC (1918) Noshomusho Tokeihyo MA C Statistical Report)

MAC (1920) Sanhinshu ni kansuru Chosa (Investigation upon Silkworm Varieties)

MAF (1927) Yosan ni kansuru Chosa (Survey on Sericulture)

\section{References}

(*in Japanese, **in Japanese with English Abstract)

Doi, T. (1973): The Use of Production Function in the Study of Regional Pattern of the Cocoon Production in Japan, 1890-1939 Res. Bul. Agr. Dev. Course 2 Hokkaido Univ.

(1974) : Regional Pattern of the Cocoon Production in Japan $(1890-1939)^{* *}$ Ann. Tohoku Geogr. Ass. 26 226 233

(1977) : Canonical Correlation Analysis on Factors Affecting Diffusion of Agricultural Innovation; A Case Study of $F_{1}$ Hybrid Silkworm in Taisho Era* Hokkaido Chiri $\mathbf{5 1}$ (forthcoming) Fujino, S. (1965): Nihon no Keikijunkan* (Business Cycle in Japan) Keiso-shobo 588 ps.

Hayami, Y. and S. Sato (1964) : Diffusion of Innovation and Structural Change in Consumer's Demand: A Study of Demand for Silk* Kikan Rironkeizaigaku (The Economic Studies Quarterly) $\quad$ 14-3 $\quad 25 \sim 36$

Ishii, K. (1972): Nihon Sanshigyoshi Bunseki* (Historical Analysis of Cocoon and Raw-silk Production in Japan) Tokyo Univ Press 460 ps.

Kondo, Y. (1932) : Sanshigyo Toseiron* (Theory on the Control of Cocoon and Raw-silk Production) Meibundo $179 \mathrm{ps}$.

Matsuo, T. (ed.) (1962): Ikushugaku Kakuron* Yokendo $684 \mathrm{ps}$.

Otsuka, Katsuo (1972): Technical Choice and Technical Progress of Silk Industry in Meiji Era* Hitotsubashi Ronso (The Hitotsubashi Review) 68 
Otsuka, Keijiro (1975): Diffusion and Improvement of Technology; A Case Study of Protected Nursery Bed* Nogyo Keizai Kenkyu (Jour. of Rural Econ.) 47

Shintani, M. (1975 a) : Labor Productivity, Employment and Factor Shares in Developing Process of Japanese Agriculture* Econ. Rev. Seinangakuin Univ. $9 \quad 87 \sim 131$

- (1975 b) : Estimation of Cocoon Supply Elasticity in Pre-war Japan Econ. Rev. Seinangakuin Univ. $10 \quad 1 \sim 22$

(1975 c) : Development of Silk Industry in Prewar Japan; An Approach from Quantitative Economic History* Econ. Rev. Seinangakuin Univ. $10 \quad 109-132$
Sakiura, S. (1974 a) : Factors Affecting Diffusion of Improved Rice Varieties in Japan* Nogyo Keizai Kenkyu (Jour. of Rural Econ.) 46 (1974 b) : Adoption of New Rice Varieties Since 1950's* Nokei Ronso (Rev. Agr. Econ. Hokkaido Univ.) $31 \quad 1 \sim 21$ (1976): The Diffusion Pattern of Improved Rice Varieties* Nokei Ronso (Rev. Agr. Econ. Hokkaido Univ.) $32 \quad 147 \sim 162$

Tarrant, J.R. (1974) : Agricultural Geography David and Charles: Newton Abbot, UK 279 ps. Yeates, M.H. (1968) : An Introduction to Quantitative Analysis in Economic Geography McGraw -Hill, N.Y. 182 ps.

\section{藏一代交雑種の普及過程 ; 1915 1921}

\section{土井時 久}

生糸輸出の急増した 1910 年から 1930 年にかけて, 藏の 派生需要増加に湌亘農家はどのように対応したか。この問 題に関し, 稀少資源としての土地の集約的利用，すなわち， 夏秋虫の増加, ならびに, 高収量, 収穫安定性品種としての 一代交雑種の意義は大きい.

本稿では, 技術革新の普及といら, 近年経済学および地理 学で取扱われてきた課題として，一代交雑種の普及に影響 を及湾す要因をさぐることを目的とする。すず, 従来の研究
成果を批判的に検討したらえで，府県別にロジスティッ ク・カープのフィットをなし，これによって得られる三つ のパラメーターの吟味をする。 ついで, そのらちの一つ, 始 発期の相違を多重回㷌分析によってあきらかにしよらとし た。結果はまだ，十分満足すべさものではないが，きわめて 急速な $\mathrm{F}_{1}$ の普及, $\mathrm{X}_{1}, \cdots \mathrm{X}_{4}$ の説明変数が，それぞれ有意な 説明力を有することが明らかにされた。 